\title{
The Women of Uzbekistan on the New Step of Development
}

\author{
Nodira Toliboeva
}

\begin{abstract}
This paper makes analyses of the women of Uzbekistan in the development step. Therefore, research conducted both theoretically and practically. Social development of the Republic of Uzbekistan has been creating better opportunities for the women and gender equality. On this case, research concludes with different shortcomings and some outcomes of the issue as the whole.
\end{abstract}

KeyWords - Uzbekistan, Development Strategies

\section{INTRODUCTION}

The new step on country's development - the women of the Republic of Uzbekistan are actively participating as a social strength in the process of modernization and intensity of democratic reforms that were intended to improve the conformation of government and society. It is inevitable to say that prosperity level of every country is vastly evaluated through the activity of women.Majority of population in society consist of the female that are widely involved in social and political field which is relevant on enhancing democratic process and strengthening civil society. As the Second President of the Republic of Uzbekistan Shavkat Mirziyoyev said: “-In our country, 45 percent of workers and employees in various spheresof life consists of female gender. About 1.4 thousands women are leading governmental and public organizations, 17 of them are the members of senate, 16 of them are deputies of Supreme Assembly Legislative Chamber and about 1.8 thousands women are members of the Local Council of Public Deputy. Nowadays more than 8 thousands of women work at municipal organizations as specialistsof feminine community and consolidation of family's cultural and moral values".

According to the statistics of 2011, executive authority system and government organizations consist $15.3 \%$ of women and $16.7 \%$ of them stand for Ministers' Cabinet. However, by contrast, this amount was $3.2 \%$ in 2005. In addition, there were $20 \%$ of women working at constitutional judicial system, $14.6 \%$ for higher judicial system, $15.8 \%$ for the system of economic courts and the leaders of municipal organizations consisted $25 \%$ of female gender.

Revised Manuscript Received on July 25, 2019

Nodira Toliboeva, Senior teacher of Uzbekistan State University of World Languages
It is worth mentioning that the people who were elected as a chairman of citizens' municipal organization of the country consisted $9.9 \%$ in 2006 by contrast with $11.5 \%$ in 2008 , as well as it became $13.4 \%$ in 2014

\section{THEORETICAL BACKGROUND}

According to the election results that were held in 2014, 13.2\% deputies of the Legislative Chamber of OliyMajlis and $16 \%$ of Senate consists of women, which shows that there are 1075 female members at the local council of people's deputies. As well as, 20\% of constitutional judicial system, $14.6 \%$ of higher judicial system, Supreme Court of the Republic of Karakalpakstan, provinces and Tashkent city courts stand for $20.4 \%$ of women. This data reflects that the participation of women in political processes is still less then by contrast of men.

The result of women's laxity in social and political process field is due to:

- Busyness of women with their family, children's upbringing and house duties when it comes to conventional and functional duty of society;

- Lack of experience on the strategy of political prerogative;

- Insufficient propagation of political career opportunities;

- Distrust of male executives to women;

- Predominance of underestimation on leadership capability of female specialists;

- Unpopularity or absence of cooperation between men and women;

- Facing the difficulties on obtaining necessary data for agitation before elections;

- Negligence on preparation of candidates in organizations;

- Minority of women in government organizations.

By analyzing the participation of women in political processes on international extent, it is clear that on average it consisted of $14 \%$ women elected for a membership in world parliament according to the data of 2000 and this number increased for $22.5 \%$ in 2015 . For instance, there are $14 \%$ percent of people elected as a state representativeare female and in general, $70.6 \%$ of women work in governmental organizations at all.

In fact, the first Ministers' Cabinet was founded in Sweden in 1995 where the amount of men and women were equal. In recent

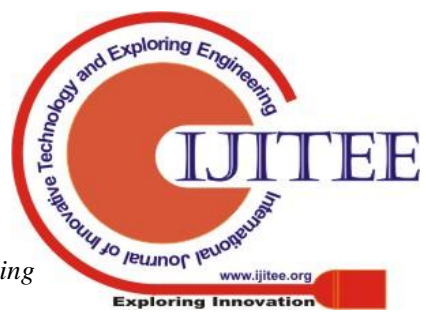


decades, the quantity of female that is involved in governmental organizations increased from $3.4 \%$ in 1987 up to $6.8 \%$ in 1995 .

It is obvious that the number of women that participate in government issues of the Republic of Kazakhstan are increasing, which means there are 3 chairwomen in Senate, 28 of them are the members of Majlis and $26.1 \%$ of all women are deputies. $36.4 \%$ of them stand for Supreme Courtof the Republic of Kazakhstan, as well as there are 13 ministers in government and 2 of them consist of women. Nevertheless, $11 \%$ of them work for general government of the state.

In Turkmenistan, the country which is located nearby to our country pays great attention to support mother child health \& safety issues, increase prestige and position of female on governing the state and society, as well as to provide equality of gender regarding to international law norms on national legislation. Principally, in national parliament of Turkmenistan 3/1 of members are female, more than $44 \%$ of them are businesswomen in economical field and $47 \%$ of them work in organizations that do not belong to a country.

It is worth mentioning that, Grant Thornton International Organization (deals with auditory services of private and public companies) defined that in Russia, $42 \%$ of those who own proprietary are women. Consequently, in Philippines there are higher amount of women (47\%) who work as a manager, by the contrast of USA with $20 \%$ and Japan has a lower rate $(7 \%)$ cause of distrust to women in business management, as well as Belgium has $12 \%$ and Denmark stands for $13 \%$ rate. Despite there are differences in underestimation of payments for the effort of women, it is undeniable to mention that in Germany, as one of the developed country in Europe, women work as a chancellor through many years. It shows that the involvement of women on state leadership and system of executive authority around the world is divided variously.

\section{DATA ANALYSES}

All of those opinions which has been mentioned above reflects that attitude towards women is superseding radically in worldwide. Active participation of women on inner and outer political issues, safety and economic development of country on a full basis is becoming a simple occasion nowadays. In modern society, the progress and prestige of every country is assessedaccording to the support and involvement of women on political processes of that country.

By analyzing and testing social inquiries on different issues among the women of Uzbekistan, "IjtimoiyFikr"social opinion research center of the Republic promulgated that socialsignificance of politics on women provided by the state has shown its priority. Particularly, there was a research on the theme: "the women of Uzbekistan - 2017: social prestige and pleasance" which has revealed the importance of female on family and society, their social support, legal advocacy, volition, their opinions and comments on current issues. This inquiry included the attendance of 1100 women living in different parts of the republic and working in state and non-state organizations, as well as businesswomen, farmers, pensioners, housewives and students. According to the consequence of the inquiry, $88.4 \%$ of respondents stated that nowadays the women of Uzbekistan are actively participating on the development of country and society, moreover, their importance has significantly increased in recent decades. More than $60 \%$ of participants expected that the authority of women would enhance on the development of state and society in upcoming future. Especially, huge incentive of working in political and social organizations of participants who are under 30 indicates that theintention of presence on state leadership among youth is strengthening greatly. Indeed, $70.2 \%$ of respondents deduced that there are sufficient privileges for women to fortify their socio-political activity and half of those participants assessed that the current activeness of women on socio-political issues is moderate. It is worth mentioning that the strategy for enhancing the involvement of women on governing the state and society is widely supported by them, as well as they favorably bolstered the expansion of women working in delegacies, executive authorities and local government organizations.

\section{THE ROLE OF WOMEN, CASE OF UZBEKISTAN}

Uzbekistan, young country which is becoming a part of world community, has its strategy that supports women not to tardily accept the impact of social scope around but to accept it actively, feel free to become a part of society, upbringing healthy children and becoming a real political subject on forming a new future.

Liveliness of women as a leader can be revealed in different socio-political spheres of society, including legislative, executive, forensic authority system, political parties, leadership of women in economic sphere as a businesswoman and those who lead cultural and moral institutions. In addition, it is inevitable to say that woman who takes on leadership should also have personal characteristics like spirituality, perfection, devotion, persuasion and patriotism. As the President Sh. Mirziyoev said: "There would be no quality advantage in state leadership unless there is a system of selecting and elaborating freely-thinking, creative, liable, initiative, progressive, patriotic and honest personnel".

By analyzing the participation of women in sociopolitical processes, there was a diligence that revealed in the following spheres. Principally, in 2016, 62.1\% leaders in high branches of healthcare ministry and 606 members of 38,023 women had a leadership position in a new system. In addition, $71.3 \%$ members in the ministry of local education, $35 \%$ of principals

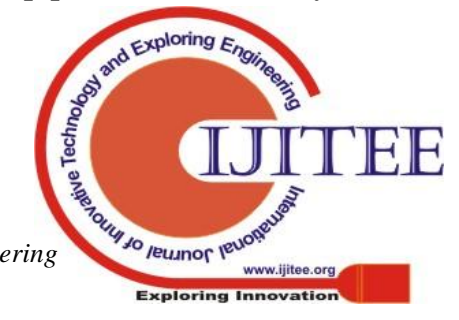


in secondary schools, $47 \%$ of principal coadjutors, $89.5 \%$ of teachers in primary education, $64.4 \%$ of secondary education and $100 \%$ of supervisors in nursery education entities consisted of women.

Totally, 16,942 leaders from 37,546 members, which are equal to $44.6 \%$, are the women who lead primary organizations of the Professional Union Federation of Uzbekistan.

To sum up, it is worth mentioning that the period of disseminating the market economy was an unavoidable process with difficulties that affected to existence level of women, as well as to their involvement in social and political life. Notably, in this periodthere was an actuation in society on religious, conventional and reborn outlook concerned with the process of self-recognition. This process had vastly negative effect on social activity of women. However, personal characteristics of Uzbek women like industriousness, patriotism, valiancy and creativity became the reason of aspiration for reaching their own prestige in society. As a result of accomplishing democratic reforms, new opportunities that were created for revealing and fulfilling the concernment of women, remained as an important function of forming themselves into active individuals, rather than being an object of social protection, in other words, necessary duty for modifying their prestige in society.

\section{RECOMMENDATIONS AND CONCLUSIONS}

By summarizing all view-points that was mentioned above, it is worth suggesting the following objectives for enhancing socio-political involvement of women, including:

- Upgrading the prestige and position of female by increasing their socio-political ken, intellectual potential and political culture;

- Extension of their involvement in citizens' municipal organizations, delegations of state leadership, Legislative House of OliyMajlis and selective positions of the Senate;

- Improving the relationship towards women in family and society, moreover, changing the attitude of male on forming the reliability to female;

- Promoting and broadening domain of public, non-state, non-commercial organizations in society that deals with the issues of female;

- Enhancing the strategy for political prerogative of women whereas political career opportunities are not thoroughly exhorted;

- In order to obtain necessary data for agitation before elections, promoting women to avoid bureaucratic interruptions and organizing the fund of supporting female candidates;

- Involving and stimulating professional community of women in order to provide their socio-political activeness;
- Intensifying the diligence of mass media and the measures that are held regularly in all parts of the country for promoting socio-political activity of women and their legal education.

\section{REFERENCES}

1. Mirziyoev Sh. Critical analysis, strict disciplinary discipline and personal responsibility - should be the daily rule of every leader's activity. The report of the President of the Republic of Uzbekistan Shavkat Mirziyoev at the enlarged meeting of the Cabinet of Ministers dedicated to the main results of socio-economic development of the country in 2016 and the most important priorities of the economic program for 2017. // "People's Word", January 15, 2016

2. Allahverdiyeva L.M. Formation and development of the system. social protection of the population, taking into account the demographic features of Uzbekistan. Author's abstract diss. ... doc econ sciences. - Tashkent, - p. 17-18

3. Karimov I.A. Uzbekistan at the turn of the twenty-first century: security threats, stability and guarantees of progress. - Tashkent: Uzbekistan, 1997. - B. 211-226.

4. The UN and the Government of Uzbekistan cooperate for the benefit of the needy people. -Company /

5. Djuraeva N. Women's Facts in the History of Uzbek Statehood // The History of the Past, full issue, 2018, №1. -B. 13. DOI http://dx.doi.org/10.26739/2181-9599/.

6. The current archive of the Women's Committee of Uzbekistan. 2018

7. Ma'rufova G. Kind, Self-sacrificing and Entrepreneur / People's Word. September 21, 2010.

8. The Current Archieve of the Women's Committee of Uzbekistan, 2018.

9. Report by the Chairperson of the Women's Committee of Uzbekistan T.Norboeva in the Reporting Conferences of the December 2018 // The current Women's Committee of Uzbekistan, 2018.

10. Report by the Chairperson of the Women's Committee of Uzbekistan T.Norboeva in the Reporting Conferences in December 2018 // The Current Archieve Committee of the Women's Committee of Uzbekistan, 2018.

11. The Current Archieve of the Women's Committee of Uzbekistan, 2018 .

12. The Current Archieve of the Women's Committee of Uzbekistan, 2018.

13. The report of the President of the Republic of Uzbekistan Sh.Mirziyoev on video conference held on November 9, 2018 devoted to the analysis of the results of the reforms in the health care system development, coverage of the population with quality medical services, strengthening the material-technical base of medical institutions, / Population, 2018. November 10

14. Report on VI Reporting Conferences of the Tashkent City Women's Committee. -Tashkent, 2018. -B.30.

15. The current archive of the Women's Committee of Uzbekistan. 2018 